\title{
Ties between Center and Periphery in the Scientific World-System: Accumulation of Rewards, Dominance and Self-Reliance in the Center
}

\author{
by \\ Thomas Schott \\ University of Pittsburgh \\ Department of Sociology \\ Pittsburgh, Pa 15260 \\ USA \\ Tel $+01-412-648-7110$ \\ Fax $+01-412-648-2799$ \\ tschott+@upitt.edu \\ World Wide Web: http://www.pitt.edu/ $\sim$ tschott
}

Cite: Schott, Thomas (1998). "Ties between Center and Periphery in the Scientific

World-System: Accumulation of Rewards, Dominance and Self-Reliance in the Center." Journal of World-Systems Research 4: 112 - 144.

(C) 1998 Thomas Schott

[Page 112]

Journal of World-Systems Research

\begin{abstract}
This study accounts for the organization of scientific research in networks of socio-intellectual ties that bind scientists into a community cultivating the scientific tradition. During the twentieth century the scientific community has become increasingly global both in the sense that its membership has spread world-widely and in the sense that its long-distance ties have intensified. The globalization of the community and its ties has been promoted by widely institutionalized arrangements, especially through the world's adoption of and belief in several scientific tenets: the universal validity of scientific knowledge, the ownership principle that knowledge should be the common property of humankind, and the political principle of granting autonomy to scientists for forming ties. The community and its network of ties form a hierarchy with centers attracting ties from peripheries. During the twentieth century the main center has shifted from Western Europe to North America while Eastern Europe has become less central, East Asia has become a bit central, and other regions have remained peripheral. A center attracts students from around the world for education, attracts scientists for conferences and visits, attracts deference from scientists throughout the world, exerts pervasive influence, is widely emulated, and is a desired source of recognition. In the global networks of ties, specifically of deference, influence, emulation and desire for recognition, there is an accumulation in the center of ties, both from within the center as
\end{abstract}


an enhanced self-reliance and from the periphery as an enhanced centrality, exceeding the research performance at the center.

Acknowledgments.

This study is part of the projects on 'International collegial ties in science' supported by the U.S. National Science Foundation (which funded the surveys in USA, Japan, France and Mexico; NSF-INT-943770) and 'Scientific research and technological invention in Denmark' supported by the Danish Social Science Research Council (which funded the survey in Denmark). Consulting revenues and grants from Sweden, Brazil and the University of Pittsburgh supported the surveys in other countries. Appreciation is expressed to the international survey staff and the scientists surveyed around the world and also to the journal's anonymous reviewer of this article. Data from the survey will become available at http://www.pitt.edu/ $\sim$ tschott.

[Page 113]

Journal of World-Systems Research

Abstract.

Acknowledgements.

Table of Contents.

Introduction.

Institutionalization of Communality in Science.

Centers of Achievement and Deference from Peripheries.

Table 1. Research for the Nobel award.

Table 2. Deference from scientists toward contributors.

People Carrying Ideas Around the World.

Table 3. Students enrolled in higher education abroad.

Table 4. Students from each nation studying in other countries.

Table 5 . Training of scientists.

Table 6. Conferences attended abroad by scientists.

Table 7. Visits by scientists to other institutions. 
Globalization of Collaboration.

Table 8. Articles coauthored between nations, 1973 and 1986.

Table 9. Articles authored within and among nations.

Circulation of Knowledge Around the World.

Table 10. Citations among authors.

Table 11. Influence on scientists from peers.

Desire for Rewards and Emulation Around the World.

Table 12. Recognition desired by scientists from colleagues.

Table 13. Emulation by scientists of colleagues.

Accumulation of Rewards and Dominance in the Center.

Table 14. Research in each region and its centrality.

Outwardness and Accumulation of Self-reliance in the Center.

Table 15. Outwardness of each region in its scientists' ties.

Table 16. Self-reliance of each region in its scientists' ties.

Conclusion: Accumulation of Ties in the Global Community.

References.

\section{Introduction}

This study accounts for the organization of scientific research in a global network of ties binding scientists into a community, its institutional conditions, and its consequences for the communal cultivation of the scientific tradition, specifically for accumulations of peripherality and centrality in rewards and dominance. This scientific world-system has a communality illustrated by the following historical event:

[Page 114]

Journal of World-Systems Research 
In 1900 in Paris, at the second "Congrès International des Mathématiciens", a lecture on "Mathematische Probleme" was given by David Hilbert in which he outlined a number of new and old unsolved problems. Through their dissemination at the meeting and in its proceedings and journals around the world, they became known as "Die Hilbertschen Probleme". Hilbert's Problems became considered especially significant, and steps toward their solution would predictably earn much recognition; indeed, "a mathematician who had solved one of them thereby passed on to the honors class of the mathematical community", as a reviewer noted. Attention to these problems, their significance, and the recognition to be expected from contributing toward a solution were enhanced by their presentation by a person who was accomplished and central in the community. The dominance of a center was perceived by a foreign visitor to Hilbert's university in Germany (Bohr, 1947):

- While Göttingen was in many ways a peaceful and quiet provincial town, the richest scientific life flourished there. An exceptionally intense and pure spirit of international brotherhood prevailed among the young mathematicians, who from nearly all countries went on a pilgrimage to the place, bound together by their common interest in and love for their science...Göttingen was an international center for mathematics and other sciences...But over the whole life in Göttingen, David Hilbert's brilliant genius shone, as if binding us all together... Almost every word he said, about problems in our science and about things in general, seemed to us strangely fresh and enriching, because everything bore the stamp of his unique originality... The whole present generation of mathematicians is - perhaps to a greater extent than many of us fully realize- under the influence of Hilbert's work and the views he brought to triumph.

The attraction to Göttingen and its wide-ranging influence illustrate the relationship between center and periphery. The center-periphery relationship was conceptualized by Shils in general terms (1988, pp. 251-252):

- The term "center" refers to a sector of society [or community] in which certain activities which have special significance or functions are relatively more highly concentrated or more intensively practiced than they are in other parts of that society and which are to a greater extent than are other parts of society the focus of attention, preoccupation, obedience, deference, or emulation.

Propositions can be specified about centers; this paper will test the following hypothesis, exemplified by Hilbert's Göttingen, (Shils, [1961] 1972, p. 357):

- A quality, additional to the persuasiveness arising form the intrinsic value of idea or deed, grows simply from emanation from the metropolis. The connection with the metropolitan center confers on an object or a symbol a quality of its own quite independently of any inherent features, so that much of what comes from the center, even though it might be no better in itself than what originates in the province, profits from the special nature of its place of origin.

Such enhancement of the status of a cen tral participant illustrates the Matthew effect found among scientists by which recognition of research increases when performed by an already recognized scientist as opposed to a lower-standing scientist (Zuckerman, 1989). Such inequitable allocation of rewards is also found in studies of the unequal exchange in international trade with respect to capital accumulation in the world economy's center and impoverization in its periphery (Amin, 1974; Emmanuel, 1972). These lines of theoretical 
and empirical inquiry are brought together here with a focus on tie accumulation in centers of science.

The hypothesis is not merely that ties accumulate in a center from around the world. It is posited that these ties accumulate not in proportion to the research performan ce of the center, but rather accrue in excess of predictions of its research performance. I shall test the hypothesis that the center accumulates ties from throughout the community, both from within the center itself as an enhancement of its self-reliance, and from peripheries as an enhancement of its centrality, over and above its research performance.

The accumulation in the center of ties from elsewhere around the world is an accumulation of its centrality. Scientists around the world are extensively tied to peers in the center because of the central peers' high research performance. However, the hypothesis is that scientists around the world are even more tied to their central peers than should be expected from the peers' research. This hypothesis can be formulated, equivalently, as the hypothesis that the peripheries are relatively deprived or ignored, that a periphery attracts even fewer ties from around the world than expected from its research performance.

[Page 115]

Journal of World-Systems Research

The multiplication of a center's ties from within itself is an accumulation of self-reliance. Scientists there rely extensively on colleagues within the center because of these colleagues' high research performance. But the hypothesis is that scientists in the center rely even more on the colleagues than should be expected from the colleagues' research. Because the center attracts so many ties from elsewhere, it is actually paradoxical and counterintuitive to posit that the center is especially non-outward.

Such studies of world science have been characterized as geopolitical because of their focus on geopolitical groupings such as nations and regions (Shrum and Bankston, 1993/94) and as network analytic because of their modeling of tie networks within and between nations and regions (Knoke, 1990, pp. 201 -202). More broadly, they are studies of a world-system and its globalization (Robertson 1992). In this study I first consider the twentieth-century global spread in the institutionalization of science as a tradition that is cultivated communally by scientists who form an increasingly global community with a network of ties that now span all regions. Then I map the global networks of ties, specifically researchers' deference toward places of scientific achie vement, their educational and scientific travel, their collaboration and influence, and finally their desire and competition for recognition as a reward. These networks reveal the centrality versus peripherality of each region and the outwardness versus se lf-reliance of the region.

Finally I test the hypothesis that ties accumulate in the center, both from around the world so as to amplify its centrality, and from within the center so as to deepen its self-reliance. I shall not examine the process of accumu lation but its outcomes, the accumulated 
centrality and the accumulated self-reliance. But first I shall consider the institutionalization of communality as an institutional foundation for the formation of a hierarchy of centers and attached peripheries.

\section{Institutionalization of Communality in Science}

Science is a tradition that is cultivated through the performance of a social role that has come to be called scientist. The script of the scientific role, the task of a scientist, is to cultivate science by contributing to the tradition, that is, by assimilating the tradition, creating knowledge that is original juxtaposed to the tradition, and contributing this original knowledge to the tradition so it becomes a modified tradition. The scientist continually assimilates the tradition by acquiring ideas from other scientists, evaluates their validity and worth, utilizes some for further research, and in turn disseminates the results of the research to other scientists. In this enactment of the scientific role, the scientist enters into role-relations with other scientists (Znaniecki, [1940] 1968). The essence of the role-relationship is the exchange of ideas. It is not only intellectual material that is exchanged. A contribution to the scientific tradition is rewarded with recognition, so knowledge is disseminated in exchange for recognition (Merton, 1973; Storer, 1966). A scientist's role-relations may thus include deference to others and caring about being rewarded in form of recognition from other scientists. Furthermore, because recognition is awarded for originality and not rediscovery or triviality, a scientist competes with peers to be first and best, and emulation thereby enters into the scientist's role-relations with other scientists. The scientist thus enacts the scientific role in a circle of other scientists, and the role-relations with this circle are not only intellectual exchanges but also social relations such as recognition and emulation (Gre, 1955; Znaniecki, [1940] 1968, 1965). A scientist's tie with another scientist, as the tie actually exits, is a bundle of analytically distinct kinds of relations, some of which are intellectual exchanges and some of which are more social relations (Burt, 1985). Characterized in terms of specificity versus diffuseness as one of Parson's pattern-variables, the tie is specific to the extent it only involves intellectual exchanges and it is diffuse to the extent it also involves social bonds. The social bond may not be epiphenomenal to the intellectual exchange; rather, there may be an embeddedness of the intellectual exchange in a social bond (Granovetter, 1985). The cultivation of science is thereby organized by the ties among scientists. The organization is neither that of a formalized hierarchy as in a bureaucracy nor that of spot exchanges in a market, but is a network of ties that tend to form spontaneously, involve some trust, and acquire some stability (Barber, 1987; Crane, 1972; Polanyi, 1967; Powell, 1990). Research is thus organized into collegial networks that remain informal although they are facilitated by a complex of international organizations, ranging from international scientific and professional association to UNESCO (Crane, 1981; Lyons 1963).

[Page 116]

Journal of World-Systems Research 
Through these role-relations and more social ties, scientists' cultivation of the scientific tradition is highly communal (Hagstrom, 1965). Scientists form a community, not only by sharing a received tradition, but also by their communal making of changes.

Contributions are subjected to rather communal evaluation and rewards are allocated rather communally. Notably, the highest reward, the Nobel Prize, is awarded on the basis of evaluations from scientists around the world and thereby the reward is actually awarded on behalf of the world's community of scientists (Zuckerman, [1977] 1996). Scientists also form a community by their interpersonal ties. Scientists are not merely fellow-members and peers but are colleagues who form intellectual and social ties with one another. Their collegial ties bind them together into a community. A scientist defers to contributors, is influenced by the works of others, emulates others, and desires recognition from peers. These ties integrate the scientist into the community and form its basic network.

The formation of ties, especially across long distances and social differences, depends on the institutionalization of science. The formation of a global scientific community has been promoted by a worldwide institutionalization of the belief that validity of propositions is universal. Scientists are convinced, partly by assimilation of a common tradition and partly by replication of experiments and observations, that truthfulness does not depend on time or place (Shapin, 1994). The occasional loss of faith in universal validity, in the twentieth century mainly under Nazism and Soviet communism, has on those occasions entailed some temporary disintegration in the community.

Furthermore, the formation of global ties also depends on the ownership principle that scientific knowledge should be the common and shared property of humankind (Daston, 1991). Conversely, appropriation of knowledge, whether by military secrecy or industrial patenting, counters the communal cultivation of the scientific tradition.

Communality also depends on autonomy. When science was first institutionalized in England, the Royal Society of London in 1662 obtained its charter from the King who granted it autonomy to form ties throughout the world, "we have given and granted ... power and authority ... to enjoy mutual intelligence and knowledge with all and all manner of strangers and foreigners" (translated from Latin and reprinted by the Royal Society of London, 1940, pp. 226-237). Since then, considerable autonomy has been granted to scientists around the world to communicate with foreigners. Wars often constrain ties between scientists in nations that are enemies. The Cold War between the communist Eastern Europe and the capitalist West hampered travels and interpersonal mail but scientific literature was disseminated across the front, as scientists insisted on maintaining some autonomy and on continuing their communal cultivation of the scientific tradition, and Soviet scientists actually continued to exchange knowledge with, to defer to, to emulate, and to desire recognition from peers in the West (Schott, 1992b).

Such a belief in universal validity, a common ownership of knowledge, and an autonomy to pursue ties with peers have become institutionalized around the world during the twentieth century. The institutionalization has been promoted at the national and global levels, especially by organizations such as UNESCO, although autonomy is often 
constrained (Ziman et al., 1986). These institutional arrangements are a foundation for the formation of a hierarchy of centers and attached peripheries (Schott, 1991, 1993, 1995, 1997, 1998a, 1998b).

\section{Centers of Achievement and Deference from Peripheries}

The community of scientists is not a community of equals because scientists differ in their accomplishments, and its network is not a uniform grid. Indeed, an accomplished scientist attracts many ties while a novice is typically ignored. Ties are especially dense between some participants and particularly sparse between some nodes. Ties are dense within a country and sparse between different nations. Ties within and to a periphery are sparse. The accomplishments of the center attract more ties, both from within the center and from peripheries.

[Page 117]

Journal of World-Systems Research

The center of science was in Italy up to the seventeenth century when it shifted to England; then it shifted to France, then to Germany, and in the twentieth century the center shifted to the United States (Ben-David, [1971] 1984). These nations were foci of attention because of their scientific achievements. The ties from scientists in peripheries to the centers have stimulated their creativity and have thereby enhanced research in the peripheries (Schott, 1987).

The twentieth-century shifts of centers can be indicated by the research contributions that have become recognized by a Nobel Prize in science, awarded almost annually since 1901 for contributions in three fields, chemistry, physics and medicine. This indicator of course falls short of perfection (in the past, apparently, the awards by the Swedish Academy of Science favored contributions from the Nordic countries) but the distribution is actually very similar to the indication of deference obtained by a survey of scientists around the world (the later Table 9). The research recognized by a Nobel award is here classified according to its place and time of performance in Table 1.

For this analysis, and especially for mapping the global networks, a classification is useful. Frequently used criteria for defining regions of the world are either attributes such as geographical location, production and civilization, or clustering according to relations, such as cohesive cliques or positions given by similarity of patterns of relations (Burt, 1983; Russett, 1967). Capturing the most common criteria, this study uses a classification of the world into the following eight regions: North America, comprising the United States of America and Canada; Western Europe, comprising Germany, France, Greece, Austria, Belgium, Denmark, Finland, Iceland, Ireland, Italy, Luxembourg, Netherlands, Norway, Portugal, Spain, Sweden, Switzerland, and the United Kingdom; Israel. Australia and New Zealand; Eastern Europe comprising the Soviet Union, Czechoslovakia, Albania, Bulgaria, Hungary, Poland, Romania, Yugoslavia, and their 
successors; Eastern Asia comprising Japan, Hong Kong, Singapore, South Korea and Taiwan; Rest of Asia comprising Asia except Israel and Eastern Asia; Latin America comprising South and Central America (including Mexico); and Africa. The only region that is not a geographical region is that of Israel, Australia and New Zealand. It is reasonable to treat these as a region in this analysis insofar as they are societies established by European settlers who brought the scientific tradition with them.

[Page 118]

Journal of World-Systems Research

Table 1.

Research for the Nobel award.

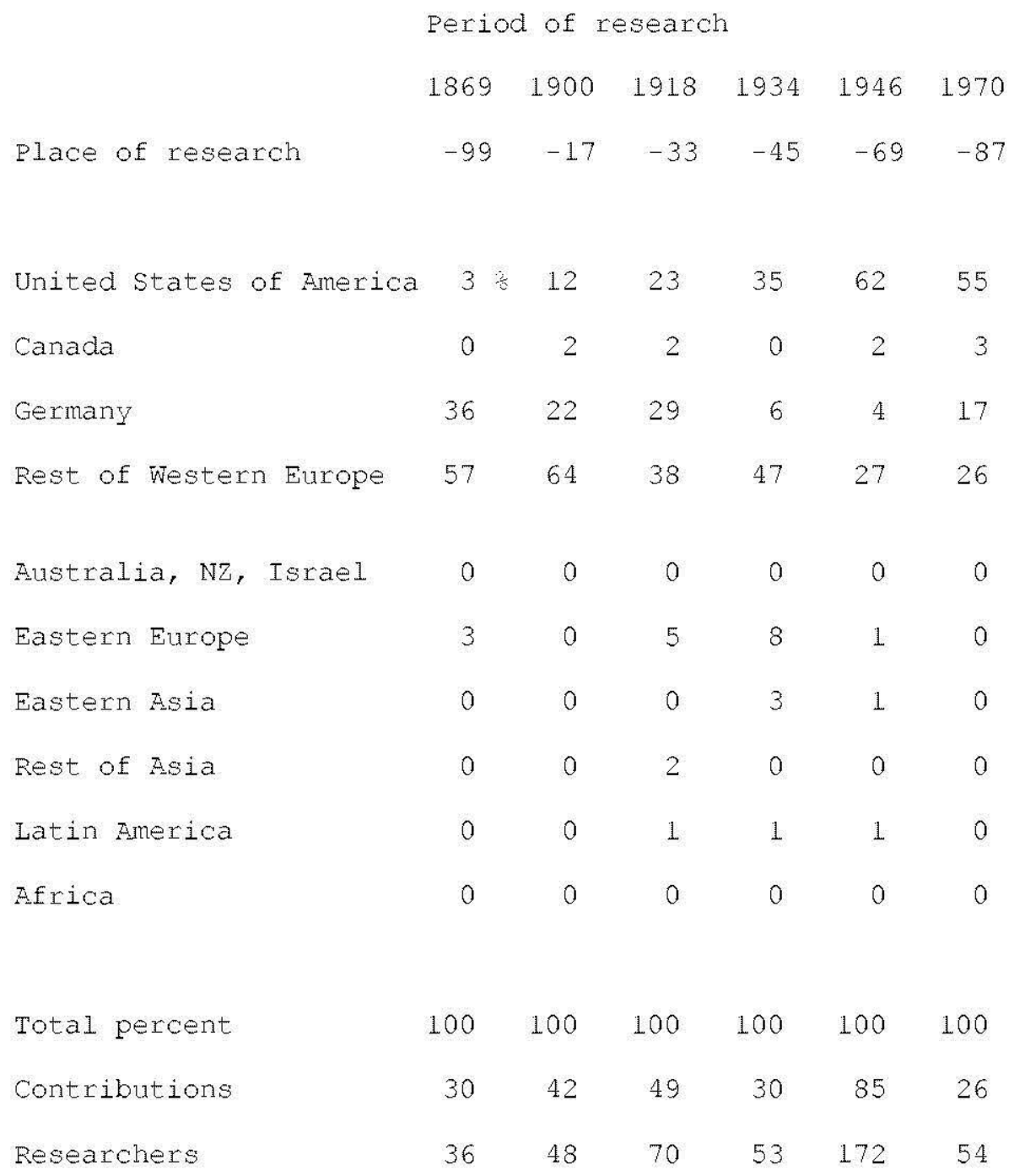


Notes: An award shared between researchers is here counted fractionally among them. In each table the percentages in a column, before rounding, sum to $100 \%$.

Sources: Wasson (1987), and other biographies (listed in Crawford et al, 1987).

Table 1 shows that, around the beginning of the 20 th century, the main center of outstanding research was in Germany. In the United States of America scientific activity was surging and around the 1920s. American achievement reach ed a level similar to that in Germany. This finding is contrary to the rather popular image that it was only after 1933 that the United States became the major center and that this centrality was due mainly to the migration of scientists from Germany to the United States which followed the Nazi takeover in 1933. The center has remained in the United States during the decades following the Second World War, with Western Europe as the secondary center.

[Page 119]

Journal of World-Systems Research

The achievements have attracted much deference around the world. Deference and other ties was tapped in a survey of scientists around the world (Schott, 1992a, 1992b, 1994, $1995,1997)$.

The survey is used extensively in this paper and can briefly be described as follows. The scientists were mostly sampled from the geographical index of the authors of the articles in the journals covered by the Science Citation Index. The survey was performed during 1990 to 1995 and has 1154 respondents around the world, with 211 in North America (all in the United States of America), 199 in Western Europe (80 in France, 67 in Denmark and 52 in Greece), 16 in Israel, Australia and New Zealand (all in Israel), 179 in Eastern Europe ( 24 in Czechoslovakia and 92 in Soviet Union before the ir disintegration and 63 in Russia), 94 in East Asia (all in Japan), 190 in the rest of Asia (66 in Bangladesh, 52 in India, 40 in Indonesia and 32 in Nepal), and 265 in Latin America (64 in Brazil, 47 in Chile, 37 in Cuba, 77 in Mexico and 40 in Uruguay).

The survey has so far not covered Africa but analyses of the global networks of bibliographic citations and coauthorships show that the structure of ties of scientists in Africa is rather similar to the structures of ties of scientists in Latin America and Asia, so the lack of surveys in Africa does not affect the generalizability of the conclusions of this study. My selection of a country within a region for surveying of course entails a reduction in representativeness, e.g. sampling Israeli scientists as representing scientists also in Australia and New Zealand. But, again, analyses of the global networks of coauthorships and citations show that the structure of ties from the sampled country is similar to the structure of ties in the other countries in the region, and therefore we can be reasonably confident that the conclusions remain valid. The few earlier surveys 
comparing many countries, though, have focused on scientists' attributes and not on their ties (e.g. Franklin, 1988; Hemptinne, 1990).

The scientist's deference to contributors was tapped by the question "Who are the five people in the world who have performed the best scientific research in your area of specialization since 1990?" (as worded in the American version used in 1995). The respondent named some contributors whose country was also queried, thereby tapping deference within and among nations.

The network of deference from scientists toward contributors is mapped in Table 2.

[Page 120]

Joumal of World-Systems Research

\section{Table 2.}

\section{Deference from scientists toward contributors.}

\begin{tabular}{|c|c|c|c|c|c|c|c|}
\hline Contributors & Scie & ntis & es exp & ress. & ng d & ferer & ce \\
\hline attracting & $\mathrm{NA}$ & WE & IA & $E E$ & $E A$ & $\mathrm{RA}$ & LA \\
\hline deference & & & & & & & \\
\hline North America & $(798)$ & 40 & 60 & 33 & 53 & 37 & 49 \\
\hline Western Europe & 18 & (54) & 15 & 24 & 25 & 28 & 33 \\
\hline Israel, Australia, NZ & 1 & 3 & (19) & 1 & 3 & 4 & 2 \\
\hline Eastern Europe & 0 & 2 & 2 & (38) & 3 & 2 & 4 \\
\hline Eastern Asia & 1 & 1 & 2 & 4 & (17) & 4 & 2 \\
\hline Rest of Asia & 0 & 1 & 2 & 0 & 0 & (24) & 0 \\
\hline Latin America & 1 & 0 & 0 & 0 & 1 & 0 & (11) \\
\hline Africa & 0 & 0 & 0 & 0 & 0 & 0 & 0 \\
\hline Total percent & 100 & 100 & 100 & 100 & 100 & 100 & 100 \\
\hline Contributors (3599) & 677 & 760 & 47 & 496 & 114 & 629 & 876 \\
\hline
\end{tabular}


The first column in Table 2 shows that North American scientists defer mostly inward, to their local contributors, and little outward, to contributors in Western Europe and elsewhere around the world. The first row shows that North American contributors attract much deference from around the world. More generally, scientists in every region defer partly inward, toward local contributors, and partly outward, especially toward contributors in North America.

In every region the deference to contributors attracted from within the region exceeds the deference they attract from any other region. The high degree of local deference can be explained as a result partly of scientists' nationalistic pride in local accomplishment, and partly of their high awareness and familiarity with local work.

But in nearly every region the outward deference is larger than the local deference. The deference expressed by the scientists in one region compared to another is actually remarkably similar. The outward deference is not cosmopolitan but is directed largely toward contributors in North America and secondarily in Western Europe.

The region that attracts most deference and thereby is most central in the network of deference is evidently North America. The second-most central region in this network is Western Europe. The other regions are peripheral in this network, they defer to the central regions but attract little deference. Juxtaposing the deferences in Table 2 with accomplishment earning Nobel awards in Table 1, it is evident that a region's centrality or peripherality in the network of deference reflects whether the region is a center or periphery of achievement.

[Page 121]

Journal of World-Systems Research

The deference entails an attraction that is expressed in travels.

\section{People Carrying Ideas Around the World.}

Ideas and knowledge are carried around by people when they move. Tacit knowledge, uncodified ideas and skills, cannot be written down for dissemination through publication, but is carried or embodied in people and is transmitted from its carrier to another person mainly through face-to-face interaction (Polanyi, 1967). Moreover, standards of evaluation, both for ascertaining the importance of unsolved problems and for judging the significance of recent contributions, are not explicated, but evaluations are 
of course ubiquitous and they tend to be formed through direct interaction among scientists. Persons pursue face-to-face interactions with others locally or they travel to interact with others. Travelers are carriers of tacit knowledge and standards and, more specifically, transmitters of their ideas and skills. A student who sojourns for research training in another place can return with research skills learnt from foreign teachers (Martin-Rovet, 1995). The researcher returning from foreign study is, in intellectual outlook, a stranger who is marginal to the local scientists, but it is the encounter of this imported learning with the local tradition which often results in a new combination of ideas. Likewise, a scientist who visits colleagues at another institution can acqui re their tacit knowledge and use it upon return (Collins, 1974; MacKenzie and Spinardi, 1995). A visit may be short and involve only a few conversations and is thus a weak tie, but because the visitor comes from a different background than the host, each $\mathrm{c}$ an present an idea that is new to the other and their ideas may be combined into a new idea. The weak tie formed by a visit is thus important, a bridge between the somewhat different cultivation of science in the two places (Granovetter, 1983). Likewise, a scientist who migrates is a carrier of the locally created tacit knowledge that can be transmitted to and stimulate researchers in the country of immigration (Hoch, 1987). A piece of tacit knowledge is carried by a sojourner or migrant from its place of creation to another place where it can beget another piece of knowledge and a synthesis can be formed. Traveling thereby counteracts parochialism in the cultivation of the tradition of science (Hoch et al., 1993).

The movement of research trainees and scientists is not a new phenomenon. Centuries ago, the intercivilizational encounter between China and Europe was highly consequential. Ancient Greece and subsequently Europe had its wandering scholars and students, their traveling was institutionalized, and when higher learning was institutionalized in a corporation called a university, this corporation was granted autonomy to move around. The institutionalization of education for young men in the European aristocracy included a Grand Tour around Europe. The ni neteenth century German universities institutionalized Wanderjahre, the principle that education preferably included a year of study at another university, and in many countries advanced research training is considered complete only after a sojourn of training in the world center. In the twentieth century, the institutionalization of scientific travel has been augmented by a global regime of rights to travel, rights that are not part of human rights and thus not accorded to all humans, but professional rights accorded to scientists for scientific purposes, although they are often curtailed (Ziman et al., 1986). Traveling has become highly institutionalized, so much that its benefits are taken for granted and policies of higher education and especially research training have in many countries around the world come to include policies for sojourning abroad (Goodwin, 1993). These policies are not locally invented but are formulated and promulgated by a complex of international organizations, mainly foundations and UNESCO with its constitutional mandate to promote the international exchange of persons active in the fields of education, science and culture and the exchange of publications' (the constitution is in, e.g., Besterman, 1951, p.115). In peripheries of the world of learning, a sojourn to the center is a credential in itself, enhancing the prestige of the sojourner, and in some peripheral countries it is even somewhat of a necessary and sufficient condition for 
certain appointments (Goodman, 1984). In the center, conversely, foreign travel is a travel to a peripheral place, and is often considered worthless or even detrimental because fewer benefits are thought to be obtainable by sojourning to the periphery than by remaining at home. This attitude prevails at the center, although its sojourners to more peripheral places assert that their sojourns are highly beneficial (Martin-Rovet and Carlson, 1995).

[Page 122]

Journal of World-Systems Research

Traveling, especially travels to and from centers, has promoted the global spread of science. The first major non-Western societies to institutionalize science were India and Japan and travels, both by local research trainees abroad and by foreign scientists to their societies, promoted the implantation and cultivation of science in these societies. Around the beginning of the 20th century, thousands of Japanese and Indian students went to learn at universities in the West and hundreds of Western scientists sojourned to work in Japan and India (Burks, 1985; Shils, 1963; Singh, 1963).

Students' travels around the world have been mapped by UNESCO since the middle of the twentieth century. In 1950 the students enrolled in higher education abroad numbered about .1 million, the number grew over the years, and in the early 1990s the students abroad reached about 1.4 million (UNESCO, 1971 and 1994), Table 3.

Table 3.

Students enrolled in higher education abroad (in millions).

$\begin{array}{llllllllll}1950 & 1955 & 1960 & 1965 & 1970 & 1975 & 1980 & 1985 & 1990 & 1993 \\ & & & & & & & & & \\ & & & & & & & & & \\ .11 & .15 & .24 & .35 & .51 & .67 & .94 & 1.02 & 1.16 & 1.35\end{array}$

Note: The numbers are a little underestimated because the surveys have not covered all countries.

Sources: UNESCO, Statistics of Students Abroad 1962-1968 (Paris: UNESCO, 1971), p.19; and Statistical Yearbook 1996 (Paris: UNESCO, 1997), and earlier editions.

The number of students abroad has increased much faster than the population in the world. Indeed, the increase in foreign study has been rather similar to expansion of higher education around the world (hence the percentage of the world's students who are enrolled abroad has been rather constant, about two percent). Considering, moreover, that opportunities for local higher education have grown around the world, so that the need to 
travel abroad for training has diminished, and considering the high costs of studying abroad, it is actually quite remarkable that study abroad has been growing so fast.

Educational travel has not been random or uniform, but has crystallized along certain routes, Table 4.

[Page 123]

Journal of World-Systems Research

\section{Table 4.}

Students from each nation studying in other countries, percent in each host country, 1962 and circa 1992.

\begin{tabular}{|c|c|c|c|c|c|c|c|c|c|}
\hline country & USA & UK & Aust. & F.SU & $\mathrm{E} \cdot \mathrm{Cz}$. & Japan & India & Arge. & Nige \\
\hline \multicolumn{10}{|c|}{ United States of America } \\
\hline 1962 & & 26 & 42 & 10 & .4 & 83 & 60 & 43 & 30 \\
\hline cal993 & & 36 & 44 & 27 & 19 & 74 & 82 & 46 & 40 \\
\hline \multicolumn{10}{|c|}{ United Kingdom } \\
\hline 1962 & 9 & & 35 & 4 & .7 & 2 & 17 & 5 & 40 \\
\hline $\operatorname{ca} 1992$ & 20 & & 12 & 1 & 3 & 3 & 3 & 1 & 15 \\
\hline \multicolumn{10}{|c|}{ Australia } \\
\hline 1962 & .4 & 1 & & 0 & 0 & .5 & 1 & 0 & .3 \\
\hline cal993 & 4 & 2 & & .2 & .3 & 1 & 1 & .3 & 0 \\
\hline \multicolumn{10}{|c|}{ Former Soviet Union } \\
\hline 1962 & $?$ & $?$ & $?$ & & 62 & $?$ & $?$ & $?$ & $?$ \\
\hline 1990 & .04 & .02 & .02 & & 30 & .02 & 5 & .6 & 20 \\
\hline \multicolumn{10}{|c|}{ Former Czechoslovakia } \\
\hline 1962 & .06 & .04 & .3 & 5 & & .4 & .04 & .8 & 1 \\
\hline 1992 & .04 & .03 & 0 & 1 & & .007 & .07 & 0 & .2 \\
\hline
\end{tabular}




\begin{tabular}{|c|c|c|c|c|c|c|c|c|c|}
\hline 1962 & .8 & .7 & .3 & 0 & 0 & & .1 & .1 & 0 \\
\hline cal 1991 & 5 & .6 & 3 & .4 & .5 & & .3 & 2 & .2 \\
\hline India & & & & & & & & & \\
\hline 1962 & .2 & .2 & .4 & 11 & 0 & .4 & & 0 & 1 \\
\hline 1987 & .6 & .3 & .1 & .1 & .03 & .06 & & 0 & 0 \\
\hline Argenti & & & & & & & & & \\
\hline 1962 & .1 & .2 & .7 & 5 & 7 & .3 & 0 & & 0 \\
\hline 1979 & .7 & .2 & 0 & .1 & .06 & .09 & .00 & & 0 \\
\hline Nigeria & & & & & & & & & \\
\hline 1962 & .1 & .3 & 0 & 0 & 0 & 0 & .04 & 0 & \\
\hline 1992 & $?$ & $?$ & $?$ & $?$ & $?$ & $?$ & $?$ & $?$ & \\
\hline Etc. & & & & & & & & & \\
\hline Total p & rcent & of the & natio & $n^{\prime} s s t$ & udents & abroa & d Isum & over & hosts) \\
\hline 1962 & 100 & 100 & 100 & 100 & 100 & 100 & 100 & 100 & 100 \\
\hline cal992 & 100 & 100 & 100 & 100 & 100 & 100 & 100 & 100 & 100 \\
\hline The nat & on's & student & s abro & $\mathrm{ad}$ & & & & & \\
\hline 1962 & 12536 & 5500 & 1139 & 436 & 453 & 3553 & 10233 & 959 & 2712 \\
\hline cal992 & 25676 & 21875 & 5125 & 11924 & 3360 & 59460 & 42341 & 4411 & 5677 \\
\hline The nat & on's & student & & & & & & & \\
\hline 1962 & & 114515 & & 29736 & & 331479 & & 183815 & \\
\hline & 22767 & & 98739 & & 84519 & & 744997 & & 6629 \\
\hline cal1992 & & 614652 & & 98206 & & 399143 & & 51542 & \\
\hline & 173106 & & 32969 & & 190409 & & 950974 & & 335824 \\
\hline Percent & ge of & nation & al stu & dents & abroad & & & & \\
\hline 1962 & .30 & .8 & 1.2 & .01 & .5 & .4 & 1.4 & .5 & 40.9 \\
\hline $\operatorname{cal} 1992$ & .18 & 1.4 & .5 & .23 & 1.8 & 2.1 & .9 & .4 & 1.7 \\
\hline
\end{tabular}

Notes: The survey of host countries, reporting students from every nation, did not cover all countries (as also indicated in the table), so the number of students abroad from a nation is a little underestimated and the listed percentage in a host country is a little overestimated. 
Sources: UNESCO, Statistics of Students Abroad, 1962-1968 (Paris: UNESCO, 1971); UNESCO, Statistical Yearbook 1996 (Paris: UNESCO, 1997) and earlier years.

[Page 124]

Journal of World-Systems Research

Table 4 shows that students from around the world have traveled mainly to the United States, which since the Second World War has been the center of higher education (Barnett and Wu, 1995; Ben-David, 1977; McMahon, 1992). Many students from the former British colonies have studied in the United Kingdom, but this enrollment has declined. Students from the communist countries sojourned mainly to the Soviet Union, but recently they have mostly been going to the United States, as shown in the case of Czechoslovakia. Traveling between the Soviet-led communist East European bloc and the capitalist Western bloc was hampered by the rivalry between the blocs. Indeed, each bloc sought allies by attracting students from around the world. Apart from this cleavage, the flow in the twentieth century has mainly been an attraction of peripheries to centers, mostly to Germany and the United Kingdom (especially from its colonies) in the first third of the century and since then mostly to the United States, the United Kingdom, France, and also to the Soviet Union from the 1950s through the 1980s. The Soviet Union and the United States rivaled, as part of their Cold War, to attract students - and thereby forge ties with the future leaders around the world - and with the end of the Cold War, efforts to attract students have diminished. In recent decades, the European Union has promoted cohesion by institutionalizing and supporting movement of scientists and students among its member nations, so a regionalization has occurred in the European Union. But the European regionalization is not typical. On the whole, the distance that students travel has been increasing, students' sojourns are increasingly to other worldregions rather than to other countries within their own region (Harmon, 1995). In terms of long-distance sojourns, there has been a globalization of higher education.

The educational bond between a teacher and a visiting student is likely to be succeeded, even upon the student's return home, by a professional tie between them. An analysis of the global networks of exchange agreements, student exchanges, and collaboration and influence between scientists in different countries, shows that the exchange agreements between countries has promoted student exchanges between them, and, in turn, the student exchanges between the countries has enhanced coll aboration and influence between the countries' scientists (Schott, 1988).

Scientists, like students, have frequently sojourned to other countries for intellectual intercourse (Martin-Rovet, 1995). Indeed, governments increasingly pursue policies of internationalization of their national research enterprises. Occasionally scientists migrate permanently. Migration has occurred in waves. With colonization some scientists sojourned and migrated from the colonizing nations to the colonized country where they pursued research in the interest of the colonial power and facilitated the institutionalization of science in the colonized society and many expatriates stayed upon 
independence (Pyenson, 1985, 1989, 1993). In societies established by European settlers some of them were also migrating scientists. Notably, the cultivation of the scientific tradition in Israel was established with a wave of migrating scientists in the interwar period and has recently been intensified by a wave of migrating scientists from the former Soviet Union (Kugel, 1993; Rodriguez, 1995). A major wave of migration of scientists was the exodus from Fascist European countries (Nazi Germany and Italy under Mussolini) to hospitable nations (especially in North America and Western Europe) (Fleming and Bailyn, 1969). Another major wave is the so-called brain drain, mainly since the 1960s, from countries with meager conditions for research (Africa, Latin America, much of Asia, and lately also Russia and other parts of Eastern Europe) to countries offering better opportunities (especially North America, lately also Western Europe and a few industrialized countries in East Asia) (Gaillard et al 1991, forthcoming). The migrations, like sojourns, have entailed a transmission of tacit knowledge and a hybridization of ideas and otherwise local traditions. The movements of people are thereby an essential component in the communal cultivation of the scientific tradition.

Most scientists in a country have been educated and trained locally, but some have also been educated abroad and are either immigrants or repatriates who have returned from studies abroad. The survey, described above, of scientists in each region also asked the scientists where they had received their highest degree. The educational origins of scientists is mapped in Table 5. The network includes scientists who immigrated to a region from another place as well as students in a region who sojourned for higher education in another place and returned to become scientists.

[Page 125]

Journal of World-Systems Research

\section{Table 5.}

Training of scientists.

\begin{tabular}{|c|c|c|c|c|c|c|c|}
\hline Place of & \multicolumn{3}{|c|}{ Scientists } & & & & \\
\hline training & $\mathrm{NA}$ & WE & IA & $E E$ & EA & $\mathrm{RA}$ & LA \\
\hline North America & $(938)$ & 4 & 31 & 0 & 0 & 24 & 14 \\
\hline Western Europe & 4 & (95) & 0 & 1 & 3 & 21 & 20 \\
\hline Israel, Australia, Nz & 0 & 0 & (63) & 0 & 0 & 5 & 0 \\
\hline Eastern Europe & 0 & 1 & 6 & $(99)$ & 0 & 3 & \\
\hline
\end{tabular}




$\begin{array}{lccccccc}\text { Eastern Asia } & 0 & 0 & 0 & 0 & (97) & 1 & 0 \\ \text { Rest of Asia } & 1 & 0 & 0 & 0 & 0 & (46) & 0 \\ \text { Latin America } & 1 & 0 & 0 & 0 & 0 & 0 & (63) \\ \text { Africa } & 0 & 0 & 0 & 0 & 0 & 0 & 0 \\ & & & & & & & \\ \text { Total percent } & 100 & 100 & 100 & 100 & 100 & 100 & 100 \\ \text { Respondents (1146) } & 210 & 199 & 16 & 179 & 89 & 189 & 264\end{array}$

Source: Survey (described earlier in the text).

The first column in Table 5 shows that North American scientists have mostly been educated locally, and a few have been educated in other regions. More generally, in nearly every region, most scientists have been educated locally, fewer have been educated elsewhere. In the surveyed Third World regions, though, around half of the scientists have been educated in other regions. The global network of education of scientists evidently has two major centers, North America and Western Europe.

Formal education is typically a single event in a career and an educational tie declines in significance during the career. Another kind of tie may be more recurrent, that of traveling to conferences. The survey asked the scientists "To which scientific conferences abroad have you gone in the years 1990 to 1995?" (in the wording used in the American survey in 1995). The network of scientists' travel abroad to conferences is mapped in Table 6.

[Page 126]

Journal of World-Systems Research

Table 6.

Conferences attended abroad by scientists.

Place of

conference

North America
Scientists going abroad

NA WE IA EE EA RA LA

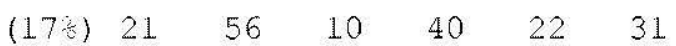




$\begin{array}{lccccccc}\text { Western Europe } & 51 & (64) & 34 & 48 & 37 & 32 & 30 \\ \text { Israel, Australia, Nz } & 5 & 2 & (0) & 0 & 3 & 4 & 1 \\ \text { Eastern Europe } & 7 & 7 & 3 & (35) & 8 & 3 & 3 \\ \text { Eastern Asia } & 9 & 2 & 7 & 2 & (4) & 11 & 3 \\ \text { Rest of Asia } & 5 & 3 & 0 & 3 & 6 & (25) & 1 \\ \text { Latin America } & 7 & 0 & 0 & 2 & 3 & 1 & 130) \\ \text { Africa } & 0 & 1 & 0 & 0 & 0 & 2 & 0 \\ & & & & & & & \\ \text { Total percent } & 100 & 100 & 100 & 100 & 100 & 100 & 100 \\ \text { Meetings (N=2444) } & 288 & 491 & 73 & 229 & 194 & 386 & 783\end{array}$

Table 6 shows that, from every region, scientists travel to conferences around the world but the global network of conferencing has its centers in North America and Western Europe.

Another kind of tie that also involves traveling is visits to other institutions. Visits to other institutions were tapped in the survey by asking "Which institutions have you visited in the last 12 months for purposes of your research?" The network of scientists' visits is mapped in Table 7.

[Page 127]

Journal of World-Systems Research

Table 7.

Visits by scientists to other institutions.

$\begin{array}{ll}\text { Place of } & \text { Scientists visiting institutions } \\ \text { institutions } & N A \text { WE IA EE EA RA LA }\end{array}$




$\begin{array}{lccccccc}\text { North America } & (85) & 11 & 54 & 5 & 15 & 12 & 21 \\ \text { Western Europe } & 10 & (77) & 15 & 25 & 14 & 20 & 17 \\ \text { Israel, Australia, Nz } & 1 & 1 & (31) & 0 & 0 & 2 & 0 \\ \text { Eastern Europe } & 1 & 5 & 0 & (67) & 7 & 0 & 2 \\ \text { Eastern Asia } & 2 & 2 & 0 & 3 & (62) & 5 & 0 \\ \text { Rest of Asia } & 1 & 2 & 0 & 0 & 1 & (60) & 1 \\ \text { Latin America } & 0 & 1 & 0 & 0 & 1 & 0 & (57) \\ \text { Africa } & 0 & 2 & 0 & 0 & 0 & 0 & 0 \\ & 100 & 100 & 100 & 100 & 100 & 100 & 100 \\ \text { Total percent } & 371 & 396 & 26 & 324 & 118 & 250 & 469 \\ \text { Visits (1954) } & & & & & & & \end{array}$

Table 7 shows that, in every region, scientists partly visit local institutions and partly visit institutions around the world. The global network of visiting, like the networks of education and conference travels, evidently has its centers in North America and Western Europe. Juxtaposing these various kinds of travels with the scientific achievements such as those earning the Nobel award (in the earlier Table 1) and deference to the achievements (in the earlier Table 2), it is evident that a region's centrality or peripherality in the networks of traveling mainly reflects whether the region is a center or periphery of achievement attracting deference.

\section{Globalization of Collaboration.}

Scientists travel to other institutions not only to disseminate their knowledge or acquire new knowledge, but also to confront their ideas with colleagues' ideas and thereby construct new knowledge, more or less as a synthesis of ideas created in the different places.

Historical change, such as a process of globalization, cannot be tapped in a survey but can be examined by using archival sources, notably the scientific literature. Collaboration 
tends to result in publications that are coauthored, so collaboration can be indicated by coauthorships. The publications authored by scientists in a country can be classified in three types, those coauthored with collaborators in other countries, those coauthored between scientists at different institutions but all within the country, and those authored by scientists who are all within a single institution in the country, Table 8 .

[Page 128]

Journal of World-Systems Research

\section{Table 8.}

Articles by scientists in a country with coauthors in various countries; percent of the articles by the scientists in the country; 1973 and 1986.

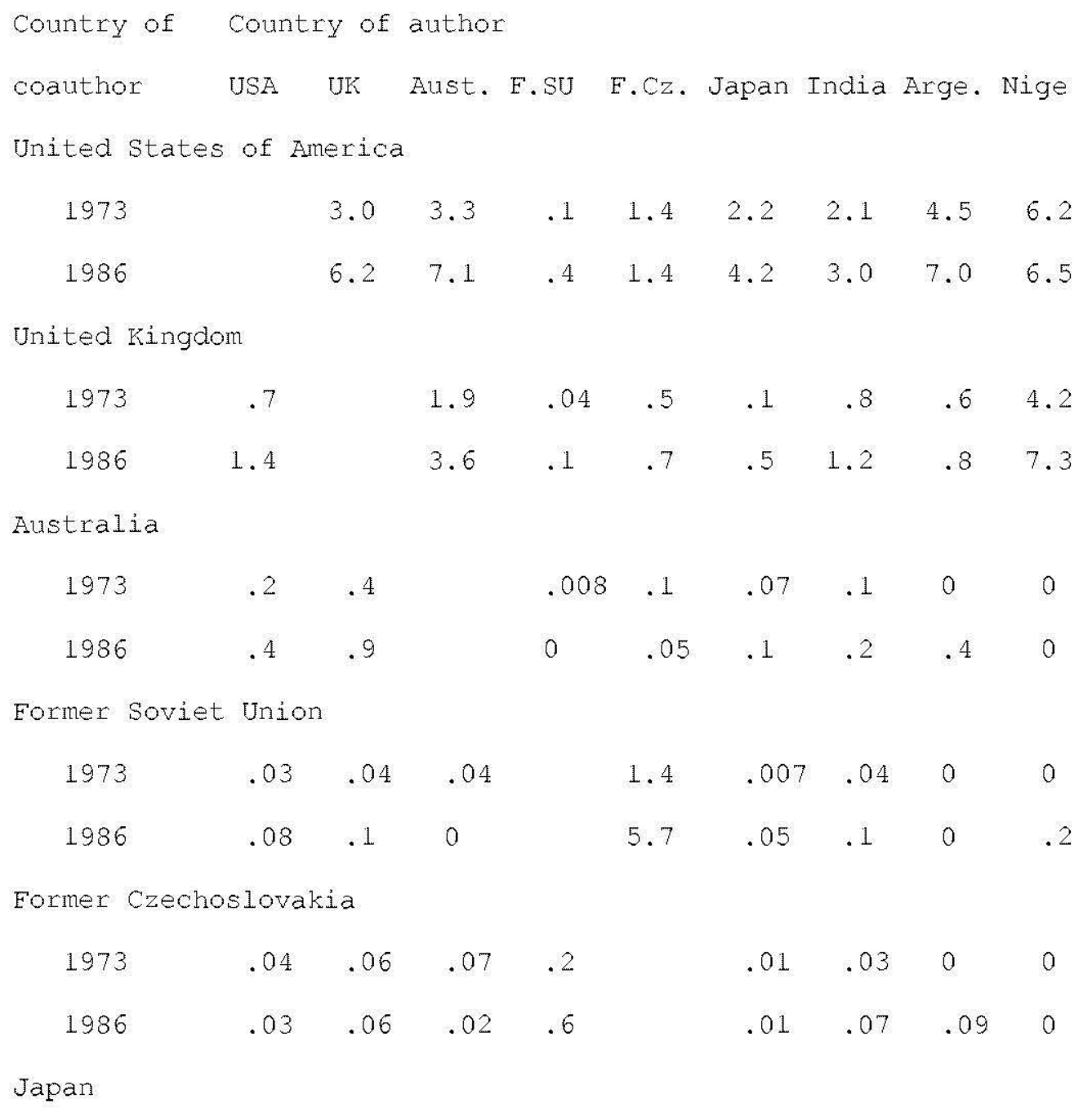




\begin{tabular}{|c|c|c|c|c|c|c|c|c|c|}
\hline 1973 & .3 & .07 & .2 & .004 & .07 & & .2 & 0 & 0 \\
\hline 1986 & .9 & .5 & .5 & .06 & .1 & & .7 & .3 & .8 \\
\hline \multicolumn{10}{|l|}{ India } \\
\hline 1973 & .1 & .2 & .2 & .01 & .07 & .1 & & 0 & 0 \\
\hline 1986 & .2 & .3 & .2 & .05 & .2 & .2 & & .09 & 1.7 \\
\hline \multicolumn{10}{|c|}{ Argentina } \\
\hline 1973 & .03 & .02 & 0 & 0 & 0 & 0 & 0 & & 0 \\
\hline 1986 & .07 & .03 & .08 & 0 & .05 & .01 & .01 & & 0 \\
\hline \multicolumn{10}{|l|}{ Nigeria } \\
\hline 1973 & .02 & .05 & 0 & 0 & 0 & 0 & 0 & 0 & \\
\hline 1986 & .03 & .1 & 0 & .005 & 0 & .02 & .1 & 0 & \\
\hline \multicolumn{10}{|l|}{ Etc. } \\
\hline \multicolumn{10}{|c|}{ Foreign coauthorships total } \\
\hline 1973 & 4.5 & 7.8 & 7.4 & 1.1 & 7.9 & 3.3 & 4.6 & 9.4 & 15.7 \\
\hline 1986 & 10.3 & 17.3 & 16.7 & 3.4 & 17.5 & 7.6 & 8.4 & 15.6 & 20.6 \\
\hline \multicolumn{10}{|c|}{ Domestic institutional coauthorships } \\
\hline 1973 & 28.0 & 14.4 & 15.8 & 11.3 & 17.3 & 16.7 & 8.4 & 23.3 & 12.4 \\
\hline 1986 & 37.6 & 22.3 & 23.7 & 12.8 & 20.4 & 30.3 & 14.1 & 25.4 & 14.8 \\
\hline \multicolumn{10}{|c|}{ Single-institution authorships } \\
\hline 1973 & 67.5 & 77.9 & 76.8 & 87.6 & 74.8 & 80.1 & 87.1 & 67.3 & 71.9 \\
\hline 1986 & 52.1 & 60.4 & 59.5 & 83.8 & 62.2 & 62.1 & 77.5 & 59.1 & 64.6 \\
\hline
\end{tabular}

Notes: The sum of the three percentages of 'Foreign coauthorships', 'Domestic coauthorships', and 'Single-institution authorships' is 100\% except for rounding.

Source: Data base acquired from Computer Horizons, Inc., compiled from the Science Citation Index.

[Page 129]

Journal of World-Systems Research 
Table 8 shows that scientists around the world have collaborated rather extensively across national boundaries. Collaboration has been centered on the United States. The United Kingdom has been a secondary center. The Soviet Union was a center within the communist Eastern Europe. Japan is becoming increasingly central. As listed at the bottom of the table, scientists in a country are decreasingly pursuing their research within a single institution, but are increasingly collaborating, both with collaborators at other institutions within the country and with collaborators in other countries. Collaboration with collaborators at other institutions within the country, though, is not increasing as fast as collaboration with foreign collaborators. The percentage of the coauthored articles that were coauthored between different nations was $13 \%$ in 1973 and grew to $20 \%$ in 1986 . We can break the data on collaboration down further, Table 9.

\section{Table 9.}

\section{Authorships within and between nations, 1973 and 1986.}

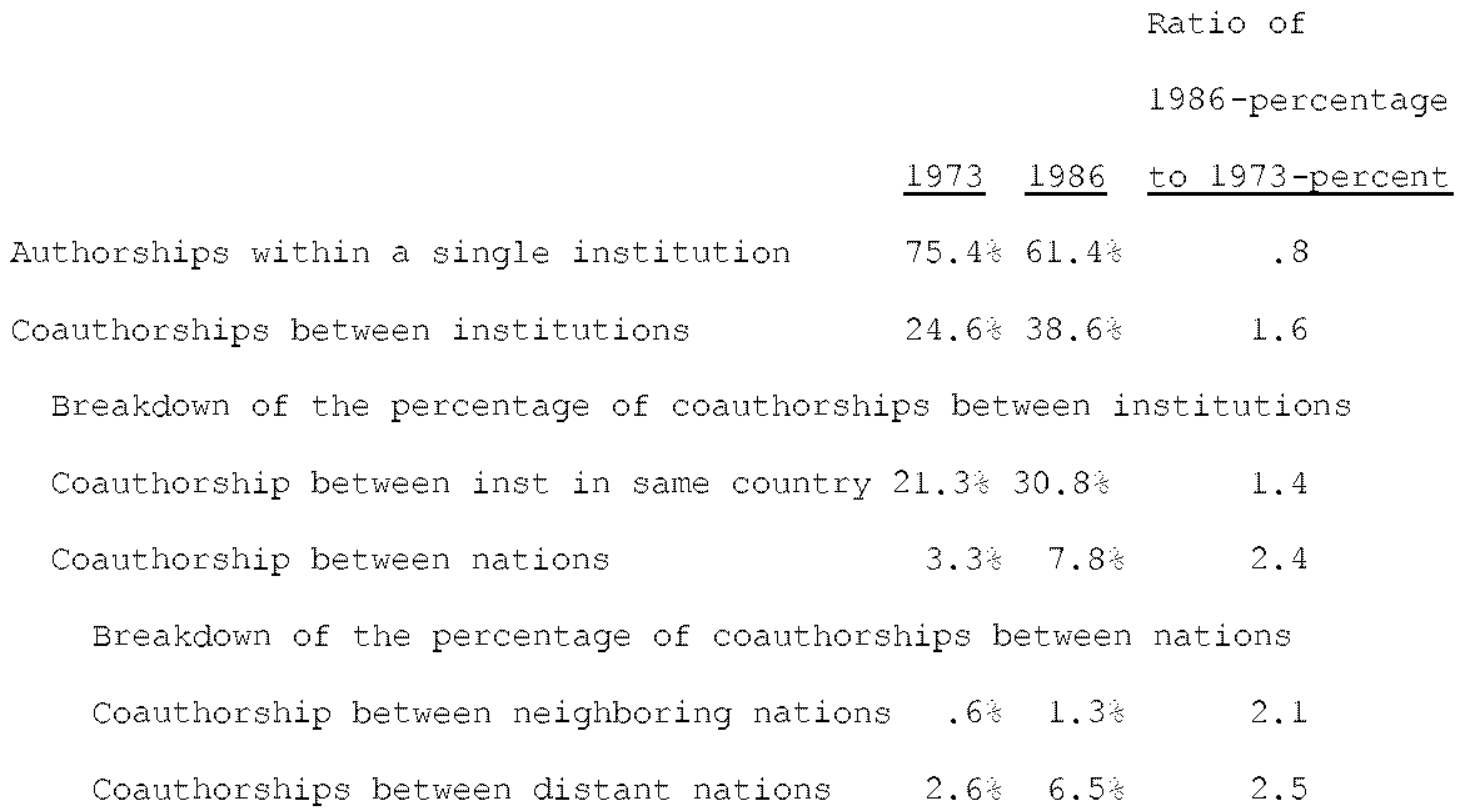

Source: Data base acquired from Computer Horizons, Inc., derived from the Science Citation Index (cf. Stevens, 1990).

Table 9 shows that long-distance ties have grown even faster than ties to neighboring nations, thus indicating an increase in the global span of collaboration, a globalization.

\section{Circulation of Knowledge Around the World}

Knowledge is carried around partly by people who travel and partly in other ways. Much scientific knowledge is disseminated through publications that, through the international postal regime, can and do circulate around the globe and are a medium for the movement 
of knowledge. The flow of knowledge in the world scientific community can be crudely indicated by citations in scientists' publications referring to local and foreign authors (Zuckerman, 1987), Table 10.

[Page 130]

Journal of World-Systems Research

\section{Table 10.}

Citations among authors.

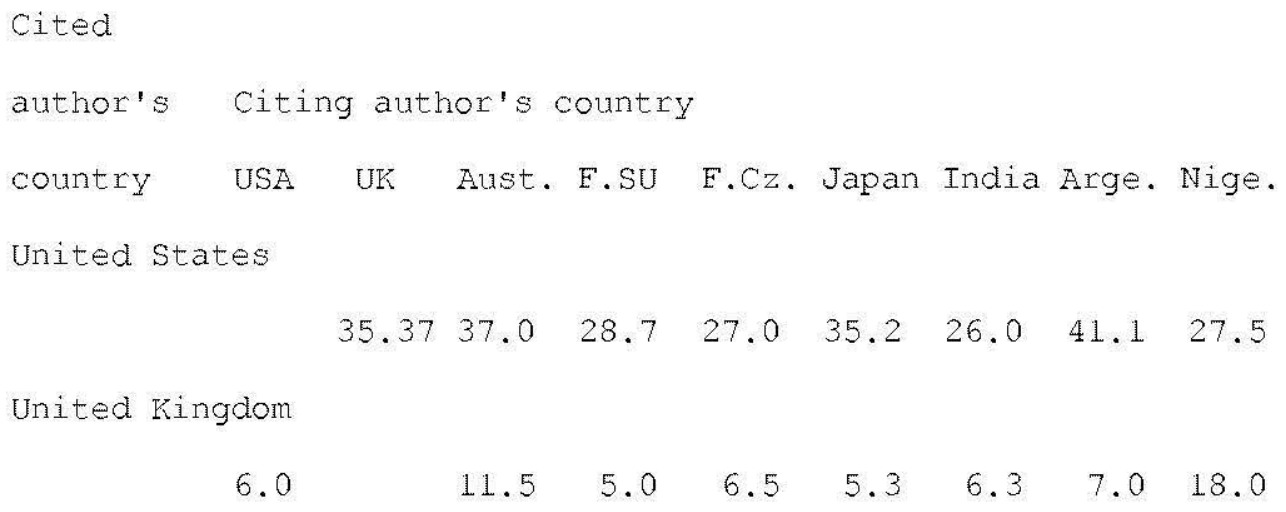
6.0
$11.5 \quad 5.0$
$6.5 \quad 5.3$
$\begin{array}{lll}6.3 & 7.0 \quad 18.0\end{array}$

Australia
1.11 .9
.8
1.
1.4 .7
2.1

Former Soviet Union

$$
\begin{array}{lllllllll}
.4 & 1.0 & .3 & .6 & 2.2 & .6 & .7 & .3 & 0
\end{array}
$$

Former Czechoslovakia

$\begin{array}{lllllllll}.4 & .3 & .1 & .4 & .4 & .2 & .2 & .09 & .2\end{array}$

Japan
2.3
2.9
2.1
3.6
4.6
3.9
$2.7 \quad 1.6$

India

$$
\begin{array}{lllllllll}
.3 & .6 & .4 & .6 & .9 & .4 & .8 & 2.3
\end{array}
$$

Argentina

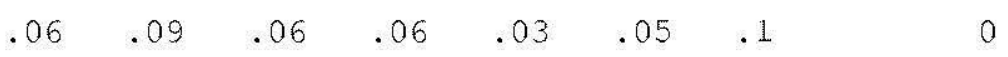

Nigeria 


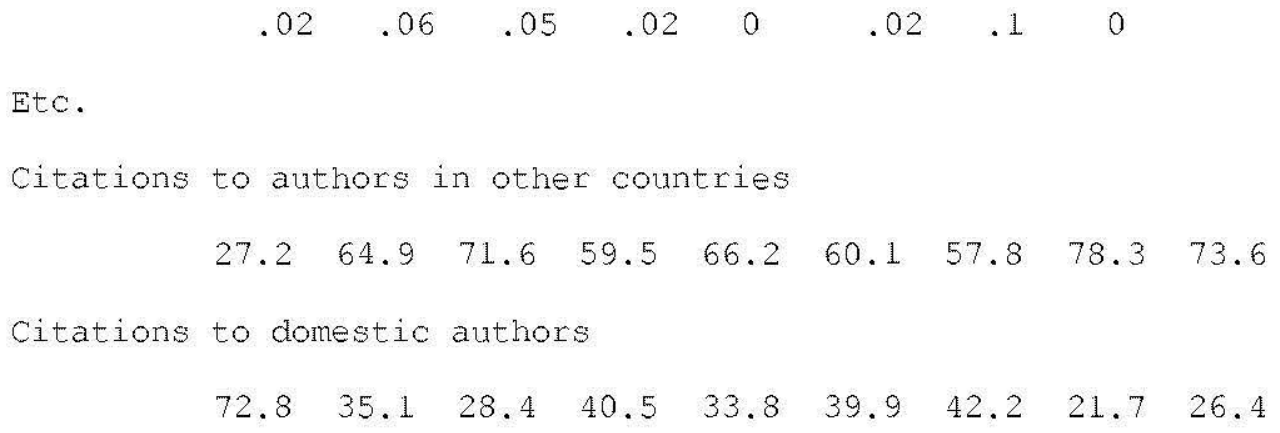

Notes: The citations to publications by domestic authors include self-citations. Citations are those in articles published in 1980-82 quoting articles published in 1978-82.

Source: Eugene Garfield, private communication; the numbers were derived from the Science Citation Index.

[Page 131]

Joumal of World-Systems Research

Table 10 shows that knowledge flows extensively across long distances, transcending national and geopolitical boundaries. But the flow is not random and even. Researchers around the world assimilate and use knowledge flowing from centers, mainly from the United States. Even researchers in the Soviet Union utilized knowledge flowing from the United States almost as much as researchers elsewhere around the world. The flow evidently transcends national and geopolitical boundaries.

Whether a globalization of the movement of knowledge has occurred can be examined by longitudinal data on the flow of citations. Numbers are available on the citations in articles published in 1976, and also citations in 1986, by scientists in the seven major countries (USA, Canada, UK, France, West Germany, Japan, and the former Soviet Union) to articles published in the most recent four years by authors in this set of countries (citations in the Science Citation Index, similar to the data described in Stevens, 1990). The percentage of the citations within and among these nations which occurred between different nations was $34.05 \%$ in 1976 and the percentage increased to $34.79 \%$ in 1986. This increase in citations between, relative to within, countries, indicates a globalization of the movement of knowledge.

The circulation of knowledge was tapped in the survey by asking the scientist "Who are the people whose ideas have influenced your research since about 1990?" The respondent named up to twenty such influences whose country was also probed. The network of influence is mapped in Table 11.

Table 11.

Influence on scientists from peers. 


\begin{tabular}{lccccccc} 
Sources of & \multicolumn{7}{c}{ Scientists receiving influence } \\
influence & NA & WE & IA & EE & EA & RA & LA \\
& & & & & & & \\
North America & $(83$ ) & 25 & 55 & 21 & 30 & 32 & 31 \\
Western Europe & 13 & $(69)$ & 13 & 19 & 13 & 21 & 23 \\
Israel, Australia, Nz & 2 & 2 & $(25)$ & 1 & 1 & 3 & 1 \\
Eastern Europe & 1 & 3 & 3 & $(55)$ & 2 & 2 & 3 \\
Eastern Asia & 1 & 1 & 4 & 3 & $(54)$ & 4 & 1 \\
Rest of Asia & 0 & 0 & 1 & 0 & 0 & $(38)$ & 0 \\
Latin America & 0 & 0 & 0 & 0 & 0 & 0 & $(40)$ \\
Africa & 0 & 0 & 0 & 0 & 0 & 1 & 0 \\
Total percent & 100 & 100 & 100 & 100 & 100 & 100 & 100 \\
Influencers & 1829 & 2039 & 110 & 1548 & 525 & 2283 & 2045
\end{tabular}

[Page 132]

Joumal of World-Systems Research

The first column in Table 11 shows that North American scientists receive influence mostly from peers in North America, some from Western Europe and little from elsewhere. The first row shows that North American science exerts pervasive influence on researchers in every region. In every region, scientists are partly inward, influenced by local colleagues, and partly outward, influenced by peers elsewhere around the world.

Juxtaposing the map of influence in Table 11 with the map of deference in Table 2 , it is evident that scientists are more local in their received influence than in their deference. In other words, the network of influence is somewhat less wide-ranging than the network of deference which extensively transcends boundaries to span the globe. The differences between the various networks will be examined later, in the section on outwardness.

\section{Desire for Rewards and Emulation Around the World.}

The institutionalization of a social activity commonly includes crystallization of a social role and a reward for performance of the role. In science, the reward for scientific 
performance is recognition. Indeed, typically, a scientist cares about receiving recognition from peers and therefore also feels competition with others for recognition.

In the survey, described earlier, a scientist's desire for recognition from others was tapped by asking, for each named influence, "To what extent do you care about each person's recognition of your research?" and the respondent rated the caring for recognition from each person on the scale from 0 for none, through 1 for little and 2 for some, up to 3 for great extent. This rated desire for recognition is used for calculating the distribution of the desire for recognition from various regions, Table 12 .

\section{Table 12.}

Recognition desired by scientists from colleagues.

\begin{tabular}{lccccccc} 
Peers valued & \multicolumn{7}{c}{ Scientists desiring recognition } \\
as recognizers & NA & WE & IA & EE & EA & RA & LA \\
& & & & & & & \\
North America & $(84$ ) & 23 & 49 & 18 & 23 & 30 & 30 \\
Western Europe & 13 & $(71)$ & 15 & 18 & 12 & 20 & 23 \\
Israel, Australia, NZ & 1 & 2 & $(28)$ & 1 & 0 & 3 & 1 \\
Eastern Europe & 1 & 2 & 4 & $(60)$ & 1 & 2 & 3 \\
Eastern Asia & 1 & 1 & 3 & 2 & $(63)$ & 3 & 1 \\
Rest of Asia & 0 & 0 & 1 & 0 & 0 & $(41)$ & 1 \\
Latin America & 0 & 0 & 0 & 0 & 0 & 0 & $(42)$ \\
Africa & 0 & 0 & 0 & 0 & 0 & 1 & 0 \\
& 1373 & 1815 & 100 & 1228 & 377 & 1708 & 1794 \\
Total percent & 100 & 100 & 100 & 100 & 100 & 100 & 100 \\
Recognizers & 1370
\end{tabular}

* The percentages in a column are based on the weighted distribution of influencers in which an influencer is weighted by the respondent's rated extent of caring about recognition from the person (cf.. the earlier description of the survey).

[Page 133]

Journal of World-Systems Research 
The first column in Table 12 shows that North American scientists desire recognition mostly from their local peers. The first row shows that North American scientists are desired sources of recognition for scientists in every region. In every region, scientists desire recognition partly from local peers and partly from peers elsewhere around the world.

The network of desire for recognition transcends geopolitical boundaries like the ties of influence and only slightly less than the globe-spanning network of deference; this will become more evident in the later analysis of outwardness (Table 15).

Rewards tend to be scarce and competition emerges. Scientists tend to emulate others in their performance of the scientific role. In the survey, described earlier, a scientist's emulation of others was tapped by asking, for each named influence, "To what extent do you feel that the person and you are competing with one another to be first or best in research?" and the respondent rated this emulation of each person on a scale from 0 for none, through 1 for little and 2 for some, up to 3 for great extent. The rated emulation is used for calculating the distribution of emulation across regions, Table 13.

Table 13.

\section{Emulation by scientists of colleagues.}

\begin{tabular}{|c|c|c|c|c|c|c|c|}
\hline Peers being & Scie & entist & $s$ exp & erie & loing & emul & tion \\
\hline emulated & $\mathrm{NA}$ & WE & IA & $E E$ & $E A$ & $R A$ & LA \\
\hline North America & $(83 \%)$ & 27 & 48 & 23 & 31 & 28 & 31 \\
\hline Western Europe & 14 & $(66)$ & 15 & 27 & 17 & 20 & 20 \\
\hline Israel, Australia, Nz & 1 & 1 & (25) & 2 & 0 & 3 & 0 \\
\hline Eastern Europe & 1 & 2 & 4 & (45) & 1 & 2 & 4 \\
\hline Eastern Asia & 1 & 3 & 6 & 3 & $(50)$ & 3 & 0 \\
\hline Rest of Asia & 0 & 1 & 1 & 0 & 0 & $(43)$ & 0 \\
\hline Latin America & 0 & 0 & 0 & 0 & 0 & 0 & (43) \\
\hline Africa & 0 & 0 & 0 & 0 & 0 & 1 & 0 \\
\hline Total percent & 100 & 100 & 100 & 100 & 100 & 100 & 100 \\
\hline Emulators (3563) & 672 & 823 & 53 & 649 & 242 & 622 & 502 \\
\hline
\end{tabular}


* The percentages in a column is based on the weighted distribution of influencers in which an influencer is weighted by the respondent's rated extent of competition with the person (cf.. the earlier description of the survey).

[Page 134]

Journal of World-Systems Research

The first column in Table 13 shows that North American scientists emulate local peers and occasionally also peers in Western Europe. The first row shows that North Americans are emulated by scientists in every region. In every region, scientists are partly inward, emulating local peers, and partly outward, emulating peers elsewhere around the world.

Emulation transcends national and regional boundaries to the same degree as influence (mapped in the earlier Table 11) and only a little less than deference (mapped in the earlier Table 2). The similarities and differences among the networks will be examined later, in the section on outwardness (Table 15).

\section{Accumulation of Rewards and Dominance in the Center.}

The global networks reveal that the overall most central region is North America. To test the hypothesis that the centrality of the center exceeds its research, centrality shall be quantified.

The mappings introduced the terms outwardness and centrality to denote outward ties and attraction of ties, respectively. The centrality of a region in a network, more precisely, denotes its tendency to attract ties from elsewhere. Similarly, the outwardness of a place denotes its tendency to send ties elsewhere. The ties from a place to another region are the ties that are sent outward from the place and are attracted to the other region. Therefore, the ties from the place to the other region depend on the tendency of the place to send ties outward and also on the tendency of the other region to attract ties. Indeed, the ties from the place to the other region may be proportional to the outwardness of the place and also proportional to the centrality of the other region. Hence, the ties from the place to the other region may be modeled as the product of the two, Ties from a place to a region $=$ Outwardness of the place * Centrality of the region.

Outwardness and centrality can be calculated from this model, using measures of the ties from each area to each other area. Statistically speaking, the measured ties are represented in a two-way table where a column lists the ties sent from a place and a row lists the ties attracted by a region, the local ties are disregarded, and the outwardness and centrality are the parameters in the multiplicative model of quasi-independence of the rows and columns in the table, and these parameters can be estimated with common software (e.g. Eliason, 1990, pp. 16-18). The outwardness parameter for a place depends essentially on how its column of ties to other areas compare to the other columns of ties 
to the other areas, and does not depend directly on its local ties. Likewise, the centrality parameter for a region depends essentially on how its row of ties received from elsewhere compares to the other rows of ties received from elsewhere. The centrality of each region can thus be calculated from a table of measured ties.

The centrality of a region in a network of ties is listed in Table 14, together with the regional share of research in the world. Research performance in a region is here indicated by its scientists' share of the articles published in the journals covered by the Science Citation Index. This indicator does not merely tap volume but also incorporates achievement because the Index mainly covers the journals that tend to publis $h$ considerable achievements.

[Page 135]

Journal of World-Systems Research

\section{Table 14.}

Research in each region and its centrality in each network.

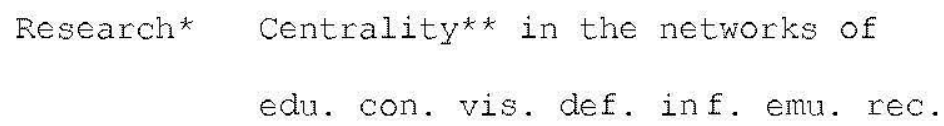

$\begin{array}{lcccccccc}\text { North America } & 39 & 51 & 37 & 44 & 58 & 57 & 54 & 55 \\ \text { Western Europe } & 36 & 33 & 42 & 40 & 32 & 31 & 34 & 33 \\ \text { Israel, Australia, Nz } & 3 & 4 & 3 & 2 & 3 & 3 & 2 & 3 \\ \text { Eastern Europe } & 6 & 9 & 6 & 6 & 3 & 4 & 4 & 4 \\ \text { Eastern Asia } & 9 & 1 & 7 & 5 & 3 & 4 & 5 & 4 \\ \text { Rest of Asia } & 4 & 1 & 3 & 2 & 1 & 0 & 1 & 1 \\ \text { Latin America } & 2 & 1 & 2 & 1 & 0 & 0 & 0 & 0 \\ \text { Africa } & 1 & 0 & 0 & 1 & 0 & 0 & 0 & 0 \\ & & & & & & & & 100\end{array}$

* Research of a region is indicated by its percentage share of articles by authors in the region, listed in the geographical section of the author index of the Science Citation Index from 1990 through 1994 (Philadelphia: Institute for Scientific Information). 
** Centrality of a region is given as its percentage of the sum total across all the regions.

Table 14 shows that the centrality of the main center, North America, substantially exceeds its research in six of the seven global networks (only in the network of conferences does the measured centrality of North America not exceed its measured research performance, but this is probably not substantively important but is likely an artifact of the comparative overrepresentation of North American research in the data source, the Science Citation Index). Conversely, the ties to the periphery, namely Africa, Latin America and the Rest of Asia, in these six networks are even fewer than predicted by the research in the periphery. This evidence corroborates the hypothesis that ties to the periphery are attenuated below its research and that ties to the center accumulate in excess of its research.

Research performance in a region was here operationalized by its share of publications in a North American reference work and this source may be somewhat biased, overrepresenting North American research and underrepresenting research performed in peripheries, and therefore the indicator may not be perfectly reliable. Notably, the North American research performance may be somewhat less than the indicated $39 \%$.

Fortunately, this unreliability does not affect the test. Specifically, if the North American performance is less than $39 \%$, there would be even more reason to conclude that the North American centrality exceeds the performance.

[Page 136]

Journal of World-Systems Research

The enhanced dominance and rewards in the center is the accumulation of external ties to the center. The accumulation of internal ties within the center is the phenomenon of selfreliance.

\section{Outwardness and the Accumulation of Self-Reliance in the Center.}

The outwardness of a region denotes the tendency of its scientists to direct their ties toward peers outside the region. The outwardness of the region can be operationalized as the estimate of a parameter in the above model. The outwardness of each region in each network of interpersonal ties is listed in Table 15. (Outwardness is not measured in the three networks of traveling because that would be inappropriate; specifically, outwardness cannot validly be measured from the network of education because this network includes migration; outwardness cannot validly be measured from the network of traveling abroad to conferences because in one region traveling abroad may be most opportune outside the region whereas in another region travel abroad may be most opportune within the region; and outwardness cannot be reliably measured from the network of visiting institutions because in the survey in one region visits to institutions may be most opportune outside the region whereas in the survey in another region visits to institutions may be most opportune within the region). 
Table 15.

Outwardness of each region in its scientists' ties.

$\begin{array}{cl} & \text { Desire for } \\ \text { Deference Influence Emulation recognition }\end{array}$

$\begin{array}{lcccc}\text { North America } & .5 & .4 & .4 & .36 \\ \text { Western Europe } & .7 & .5 & .5 & .42 \\ \text { Israel,Australia, NZ } & .8 & .8 & .8 & .7 \\ \text { Eastern Europe } & .6 & .5 & .6 & .41 \\ \text { Eastern Asia } & .9 & .5 & .5 & .37 \\ \text { Rest of Asia } & .8 & .6 & .6 & .6 \\ \text { Latin America } & .9 & .6 & .6 & .6 \\ & & & & \\ \text { Mean outwardness } & .7 & .5 & .6 & .5\end{array}$

Table 15 shows that outwardness differs among the regions, which will be compared shortly (Table 16), and differs among the networks. The overall outwardness prevailing in a network, as indicated by the mean listed at the bottom of Table 15, is higher for deference than for the other networks. Scientists are more outward deferential than they are outward in their networks of influence, emulation and desire for recognition.

[Page 137]

Journal of World-Systems Research

The self-reliance of a region in a network of ties is the tendency of the scientists in the region to direct their ties toward peers within the region. The self-reliance is thus the opposite of their outwardness and can therefore be measured as the reciprocal of the outwardness (as noted above, this parameter does not directly reflect the local ties, so 
self-reliance is not a mere reflection of local ties but is a comparative characteristic). The self-reliance of each region in the four interpersonal networks is listed in Table 16.

Table 16.

Self-reliance of each region in its scientists' ties.

Deference Influence Emulation Desire for Mean

recognition self-reliance

$\begin{array}{lccccc}\text { North America } & 2.0 & 2.5 & 2.7 & 2.8 & 2.5 \\ \text { Western Europe } & 1.5 & 2.2 & 1.9 & 2.4 & 2.0 \\ \text { Israel, Australia, Nz } & 1.2 & 1.3 & 1.3 & 1.3 & 1.3 \\ \text { Eastern Europe } & 1.6 & 2.2 & 1.7 & 2.5 & 2.0 \\ \text { Eastern Asia } & 1.1 & 2.1 & 1.9 & 2.7 & 1.9 \\ \text { Rest of Asia } & 1.3 & 1.6 & 1.7 & 1.7 & 1.6 \\ \text { Latin America } & 1.1 & 1.7 & 1.8 & 1.7 & 1.6 \\ & & & & & \end{array}$

The first column in Table 16 shows that self-reliance in the deferential ties is far higher in North America than in any other region. The second column shows that North American research is also especially self-reliant in the network of susceptibility to influence from various regions. North American scientists are also more locally reliant in their emulation of peers than scientists in any other region. The fourth column shows that North American scientists are also especially locally reliant in their desire for recognition from peers. Across the networks, as indicated by the mean listed in the last column, North American research is considerably more self-reliant than the research in any other region. This evidence corroborates the hypothesis that the center is especially self-reliant.

\section{Conclusions: Accumulation of Ties in the Global Community.}

Up to the late-19th century science was institutionalized and communally cultivated within the Western civilization, as a world-system spanning Europe and later spanning the West, while every other civilization cultivated its indigenous traditions of knowledge. The 20th century historical process of globalization of science comprises two phenomena. First, science became global in that it spread and underwent institutionalization by obtaining legitimation, autonomy, support and organization in virtually every society around the world. Second, the cultivation of science became 
global in that it became cultivated communally as well as globally, through globespanning movements of ideas and people who by these globe-spanning collegial ties formed not only national communities but actually also a global community. This communality has been founded on widespread institutionalizations of a faith in universal validity of scientific knowledge, of a political economy of knowledge stipulating that scientific knowledge should belong to humankind, and of a principle of granting autonomy and even support to scientists to form collegial ties with peers around the world.

[Page 138]

Journal of World-Systems Research

The movements of people, as examined in this article, for higher education, for training as scientists, for attending conferences abroad, and for visiting colleagues at other institutions, have been extended to span the globe. Their collaboration in the creation of new ideas has become more global. The circulation of ideas has become more global. Scientists mostly defer to and desire recognition from distant colleagues.

The globalization of movements of people, ideas and recognition did not entail any equalization but crystallized recurrently into a periphery and center formation. Up to the early 1930s scientific achievement was higher in Germany than anywhere else and made Germany the center and since the Second World War the United States has been the major center. The scientific achievement and ideas attracted attention from people throughout the world of learning, the temporary and permanent migration of people was mainly from the periphery to the center, and the circulation of ideas was mainly from the center to the periphery.

The recurrent unequal exchanges between periphery and center exacerbated the inequality between them. Attention to the periphery was attenuated and its share became even less than its share of research. Conversely, centrality accumulated in the center and its shares of recognition and influence became even larger than its share of research. The accumulation of ties to the center from around the world was accompanied by an accumulation of ties from within itself. The center's scientists' deference, desire for recognition and susceptibility to influence accumulated were even less outward than expected, so that the center was especially self-reliant.

The ties from the peripheries to the centers have stimulated research in the peripheries, elevated the dominance of the centers over and above its research performance, strengthened the cohesion of the global scientific community, and enhanced the coherence of the cultivation of the scientific tradition.

Science and its communal cultivation have become institutionalized around the world, so much that its benefits, to individuals, to nations and to humankind, have become taken for granted. Indeed, whereas many states in the decades after the Second World War 
pursued policies for the 'nationalization' of research in the country, they have recently been elaborating policies of 'internationalization' of their national research enterprises, including policies for joint research facilities, support for collaboration among scientists, and for sending and receiving research trainees. The national policies have been not so much nationally invented as they have been formulated and promulgated by a web of international organizations led by agencies of modernity such as the Organisation for Economic Co-operation and Development (OECD) and Western-dominated agencies of modernization around the world such as the United Nations Educational, Scientific and Cultural Organization (UNESCO) with its constitutional mandate to promote the international exchange of persons active in the fields of education, science and culture and the exchange of publications'. The globalization of science and its communal cultivation have thereby been part of the projects of modernization and globalization of social and intellectual life.

[Page 139]

Journal of World-Systems Research

\section{$\underline{\text { References }}$}

Amin, Samir. 1974. Accumulation on a World Scale. (New York: Monthly Review Press).

Barber, Bernard. 1987. 'Trust in science.' Minerva, 25:123-134.

Barnett, George A., and Reggie Yingli Wu. 1995. The international student exchange network: 1970 \& 1989.' Higher Education, 30:353-368.

Ben-David, Joseph. 1977. Centers of Learning: Britain, France, Germany, United States. (New York: McGraw Hill).

Ben-David, Joseph. 1984 [1971]. The Scientist's Role in Society: A Comparative Study. (Chicago: University of Chicago Press).

Besterman, Theodore. 1951. UNESCO: Peace in the Minds of Men. (New York: Praeger).

Bohr, Harald. 1947. "Et tilbageblik", Matematisk Tidsskrift, A, 1:1-27; translated as 'Looking backward', in H. Bohr, Collected Mathematical Works (Copenhagen: Dansk Matematisk Forening), I, pp. xii-xxxiv.

Burks, A. W. 1985. The Modernizers: Overseas Students, Foreign Employees, and Meiji Japan. (Boulder: Westview Press). 
Burt, Ronald S. 1983. 'Cohesion versus structural equivalence as a basis for network subgroups'. In R. S. Burt and M. J. Minor (eds.), Applied Network Analysis: A Methodological Introduction. (Beverly Hills: Sage), 262-282.

Burt, Ronald S. 1985. 'Relation contents in multiple networks.' Social Science Research, 14:287-308.

Collins, Harry, 1974. 'The TEA set: tacit knowledge and scientific networks.' Science Studies, 4:165-186.

Crane, Diana. 1972. Invisible Colleges: Diffusion of Knowledge in Scientific

Communities. (Chicago: University of Chicago Press).

Crane, Diana. 1981. 'Alternative models of ISPAs.' In William M. Evan (ed.), Knowledge and Power in a Global Society. (Beverly Hills, Ca.: Sage), pp. 29-47.

Crawford, Elisabeth, Heilbron, John, and Rebecca Ullrich. 1987. The Nobel Population, 1902-1937. (Berkeley: Office of History of Science and Technology).

Daston, Lorraine. 1991. 'The ideal and reality of the Republic of Letters in the Enlightenment'. Science in Context, 4:367-386.

Eliason, Scott R. 1990. The Categorical Data Analysis System. Version 3.50 User's Manual. (Iowa City: University of Iowa, Department of Sociology).

Emmanuel, Arghiri. 1972. Unequal Exchange: A Study in the Imperialism of Trade. (New York: Monthly Review Press).

Fleming, Donald, and Bernard Bailyn (eds.). 1969. The Intellectual Migration: Europe and America, 1930-1960. (Cambridge, Ma: Belknap Press).

[Page 140]

Joumal of World-Systems Research

Franklin, Mark. 1988. The Community of Science in Europe. (Aldershot: Gower).

Gaillard, Jacques. 1991. Scientists in the Third World. (Lexington, Ky: University Press of Kentucky).

Gaillard, Jacques (ed.). In press. Les Cooperations Scientifiques Internationales. (Bondy: Orstom-Editions).

Gaillard, Jacques, V.V.Krishna, R.Waast (eds.). 1997. Scientific Communities in the Developing World. (New Delhi: Sage India). 
Goodman, Norman. 1984. In Elinor G. Barber, Philip G. Altbach, and Robert G. Myers (eds.), Bridges to Knowledge: Foreign Students in Comparative Perspective. (Chicago: University of Chicago Press),

Goodwin, C. D. (ed.). 1993. International Investment in Human Capital: Overseas Education for Development. (New York: Institute of International Education).

Granovetter, Mark. 1983. 'The strength of weak ties: a network theory revisited.' In Randall Collins (ed.), Sociological Theory, 1983. (San Francisco: Jossey-Bass), 201-233.

Granovetter, Mark. 1985. 'Economic action and social structure: the problem of embeddedness.' American Journal of Sociology, 91:481-510.

Gre, Gerald L. De. 1955. Science as a Social Institution. (New York: Doubleday).

Hagstrom, Warren. 1965. The Scientific Community. (New York: Basic Books).

Harmon, Matthew. 1995. 'Patterns of international study: 1969-1991.' Paper presented at the Annual Meeting of the Pennsylvania Sociological Society, Philadelphia.

Hemptinne, Yvan. 1990. 'Evaluating R\&D units for effectiveness and productivity: the UNESCO-sponsored ICOPRU'. In Bernard Crousse, Jon Alexander and Rejean Landry (eds.), Evaluation des Politiques Scientifiques et Technologiques: Experiences Nationales. (Quebec: Les Presses de l'Universite Laval), 205-221.

Hoch, Paul. 1987. 'Migration and the generation of new scientific ideas.' Minerva, 25:209-237.

Hoch, Paul, and Jennifer Platt. 1993. 'Migration and the denationalization of science.' In Elisabeth Crawford, Terry Shinn and Sverker Sörlin (eds.), Denationalizing Science: The Contexts of International Scientific Practice. (Dordrecht: Kluwer), 133-152.

Institute for Scientific Information. Annually. Science Citation Index. (Philadelphia: ISI).

Knoke, David. 1990. Political Networks: The Structural Perspective. (Cambridge: Cambridge University Press).

Kugel, Samuel A. (ed.). 1993. Intellektualnaia migratsiia v Rossii [Intellectual Migration in Russia]. (Sankt-Peterburg: Politekhnika).

Lyons, F. S. L. 1963. Internationalism in Europe 1815-1914. (Leyden: Sythoff).

MacKenzie, Donald, and Graham Spinardi. 1995 'Tacit knowledge, weapons design, and the uninvention of nuclear weapons.' American Journal of Sociology, 101:44-99. 
Martin-Rovet, Dominique. 1995. 'Young French scientists in the United States.' Minerva, 33:75-98.

Martin-Rovet, Dominique, and Timothy Carlson. 1995. 'American scientists in France.' Minerva, 33:171-191.

[Page 141]

Journal of World-Systems Research

McMahon, Mary E. 1992. 'Higher education in a world market: an historical look at the global context of international study.' Higher Education, 24:465-482.

Merton, Robert K. 1973. The Sociology of Science. (Chicago: University of Chicago Press).

Polanyi, Michael. 1967. The Tacit Dimension. (London: Routledge).

Powell, Walter W. 1990. 'Neither market nor hierarchy: network forms of organization.' In Barry Staw and Larry L. Cummings (eds.), Research in Organizational Behavior, $12: 295-336$.

Pyenson, Lewis. 1985. Cultural Imperialism: German Expansion Overseas, 1900-1930. (New York: Lang).

Pyenson, Lewis. 1989. Empire of Reason: Exact Sciences in Indonesia, 1840-1940. (Leiden: Brill).

Pyenson, Lewis. 1993. Civilizing Mission: Exact Sciences and French Overseas Expansion, 1830-1940. (Baltimore: Johns Hopkins University Press).

Robertson, Roland. 1992. Globalization: Social Theory and Global Culture. (London: Sage).

Rodriguez, Keri L. 1995. 'Russian scientists' integration into the world scientific community.' Paper presented at the Annual Meeting of the Pennsylvania Sociological Society, Philadelphia.

Royal Society of London. 1940. Record of the Royal Society of London. (London: Royal Society of London).

Russett, Bruce M. 1967. International Regions and the International System: A Study in Political Ecology. (Westport, Conn.: Greenwood Press). 
Schott, Thomas. 1987. 'Scientific productivity and international integration of small countries: mathematics in Denmark and Israel'. Minerva, 25:3-20.

Schott, Thomas. 1988. 'International influence in science: beyond center and periphery.' Social Science Research, 17:219-238.

Schott, Thomas. 1991. 'The world scientific community: globality and globalisation.' Minerva, 29:440-462.

Schott, Thomas. 1992a. 'Scientific research in Sweden: orientation toward the American centre and embeddedness in Nordic and European environments.' Science Studies, 5 , 2:13-27.

Schott, Thomas. 1992b. 'Soviet science in the scientific world system: was it autarchic, self-reliant, distinctive, isolated, peripheral, central?' Knowledge: Creation, Diffusion, \& Utilization, 13:410-439.

Schott, Thomas. 1993. 'World science: globalization of institutions and participation.' Science, Technology, \& Human Values, 18:196-208.

Schott, Thomas. 1994. 'Emerging and declining centers of engineering science: Japan and The United States.' Knowledge: Creation, Diffusion, \& Utilization, 15:417-456.

Schott, Thomas. 1995. 'Performance, specialization and international integration of science in Brazil: changes and comparisons with other Latin American countries and Israel.' In S. Schwartzman (coord.), C. Bertero, E. Guimaraes, E. Krieger, E. Skolnikoff, F. Galembeck, G. Ferné, L. Branscomb, M. Gibbons, and T. Schott, Science and Technology in Brazil: A New Policy for a Global World. (Rio de Janeiro: Fundaçao Getulio Vargas), pp. 227-284.

[Page 142]

Journal of World-Systems Research

Schott, Thomas. 1997. 'The global-national nexus in research: Absorbing world science in Denmark.' LIBRI - International Journal of Library and Information Science, 47:193205.

Schott, Thomas, Samuel Kugel, Keri Rodriguez and Reuben Berrios. 1998a. 'Peripheries in world science: Latin America and Eastern Europe.' In Mike-Frank Epitropoulos and Victor Roudometof (eds.), American Culture in Europe: Interdisciplinary Perspectives. (Greenwood Publ) [In press].

Schott, Thomas, Jun Kanamitsu and James F. Luther. 1998b. The U.S. center of world science and emulating centers: Japan and Western Europe. 'In Mike-Frank Epitropoulos 
and Victor Roudometof (eds.), American Culture in Europe: Interdisciplinary

Perspectives. (Greenwood Publ) [In press].

Shapin, Steven. 1994. A Social History of Truth. (Chicago: University of Chicago Press).

Shils, Edward. 1963. 'Foreword: The foreign returned.' In Amar Kumar Singh, Indian Students in Britain: A Survey of Their Adjustments and Attitudes. (Bombay: Asia Publishing House), vii-xv.

Shils, Edward. [1961] 1972. 'Metropolis and province in the intellectual community'. In Edward Shils, The Intellectuals and the Powers, and Other Essays. (Chicago: University of Chicago Press), 355-371.

Shils, Edward. 1988. 'Center and periphery: an idea and its career, 1935-1987'. In Liah Greenfeld and Michel Martin (eds.), Center: Ideas and Institutions. (Chicago: University of Chicago Press), 250-282.

Shrum, Wesley, and Carl Bankston. 1993/94. 'Organizational and geopolitical approaches to international science and technology networks'. Knowledge and Policy, 6:119-133.

Singh, Amar Kumar. 1963. Indian Students in Britain: A Survey of their Adjustments and Attitudes. (Bombay: Asia Publishing House).

Stevens, Kim. 1990. Updating and Maintaining Fourteen Bibliometric Data Series Through 1986. (Haddon Heights, N.J.: CHI Research, Inc.).

United Nations Educational, Scientific and Cultural Organization. Annually. Statistical Yearbook. (Paris: UNESCO).

United Nations Educational, Scientific and Cultural Organization. 1971. Statistics of Students Abroad 1962-1968. (Paris: UNESCO).

United Nations Educational, Scientific and Cultural Organization. 1976. Statistics of Students Abroad 1969-1973. (Paris: UNESCO).

United Nations Educational, Scientific and Cultural Organization. 1982. Statistics of Students Abroad 1974-1978. (Paris: UNESCO).

Wasson, T. (ed.). 1987. Nobel Prize Winners. (New York: H. W. Wilson).

Ziman, John, Paul Sieghart, and John Humphrey. 1986. The World of Science and the Rule of Law. (Oxford: Oxford University Press).

Znaniecki, Florian. [1940] 1968. The Social Role of the Man of Knowledge. (New York: Harper). 
Znaniecki, Florian. 1965. Social Relations and Social Roles. (San Francisco: Chandler).

Zuckerman, Harriet. [1977] 1996. Scientific Elite: Nobel Laureates in the United States. (New York: Free Press).

[Page 143]

Journal of World-Systems Research

Zuckerman, Harriet. 1987. 'Citation analysis and the complex problem of intellectual influence.' Scientometrics, 12:329-338.

Zuckerman, Harriet. 1989. 'Accumulation of advantage and disadvantage: the theory and its intellectual biography'. In Carlo Mongardini and Simonetta Tabboni (eds.), L'Opera di R. K. Merton e la Sociologia Contemporanea. (Genoa: Edizioni Culturali Internazionali Genova), 153-176.

[Page 144]

Journal of World-Systems Research 